\title{
研究報告
}

\section{多結晶アルミニウムの圧延集合組織におよぼす マグネシウムの影響}

\author{
高橋 恒夫*・橋本 正興**・村上 雄* \\ Influence of magnesium on the rolling texture of polycrystalline aluminum \\ UDC $669.71: 669.715^{\prime} 721: 548.23$ \\ TAKAHASHI Tsuneo*, HASHIMOTO Masaoki** and MURAKAMI Takeshi*
}

The effects of the magnesium content, the rolling temperature and the rolling reduction on polycrystalline aluminum were studied. When the rolling reduction was $95 \%$, the rolling texture of polycrystalline aluminum changed gradually from the copper type to the brass type as the magnesium content increased. The lowering of rolling temperature favored the component of the brass type texture. This was significant in the $\mathrm{Al}-\mathrm{Mg}$ alloy. At $50 \%$ reduction, the main component of the rolling texture in pure aluminum and an $\mathrm{Al}-3 \% \mathrm{Mg}$ alloy was $\{112\}\langle 111\rangle$. However, when the reduction was larger than $50 \%$, the orientation in aluminum and the $\mathrm{Al}-\mathrm{Mg}$ alloy tended to approach to $\{146\}\langle 211\rangle$. The transition from $\{112\}\langle 111\rangle$ to $\{146\}\langle 211\rangle$ occurred in the smaller reduction in the alloy than in pure aluminum.

(Received July 19, 1973)

\section{1. 緒言}

面心立方晶金属においては純金属型（あるいは銅型） および合金型（あるいは黄銅型）と呼称される二種類の 異なつた圧延集合組織が形成され，その原因については 積層欠陥エネルギーと関連のある潜在す心゙り系の硬

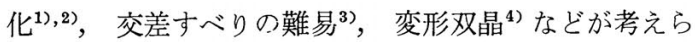
れている。

一方アルミニウムにおいては，その積層欠陥エネルギ 一が大きいため，典型的な純金属型の圧延集合組織が形 成されるが， $\mathrm{Al}-\mathrm{Fe}^{5)}, \mathrm{Al}-\mathrm{Cu}, \mathrm{Al}-\mathrm{Si}$ 合金6),7) などにおい ては，溶体化後焼入れたのち圧延すると合金型の $\{011\}$ <211>成分がわずかに増加することが認められている。 本論文では， $\mathrm{Al}-\mathrm{Mg}$ 合金においてマグネシウム添加 量に対する圧延集合組織の変化を調べた結果を報告す る。

\section{2. 実験方法}

実験には純度 $99.8 \%$ の純アルミニウム鋳塊扩よびそれ に 0.7, 1.5, $3.0 \mathrm{wt} \%$ のマグネシウムを添加した計 4 種類 の試料を用いた。各試料を黒鉛るつぼ中で溶解し，700
${ }^{\circ} \mathrm{C}$ で金型に鋳込み， $153 \times 120 \times 10 \mathrm{~mm}^{3}$ のスラブとし た。このスラブを厚さ $4 \mathrm{~mm}$ まで両面を研削し， $450^{\circ} \mathrm{C}$ で24時閒均質化焼鈍を行なつた。この後，25\%予備圧延 して厚さ $3 \mathrm{~mm}$ とした。この過程において，試料の鋳造 組織はほとんど消滅した。つぎに純アルミニウムおよび それに 0.7, $1.53 .0 \mathrm{wt} \%$ マ\%グネシウムを添加した合金を それぞれ $450{ }^{\circ} \mathrm{C}$ で 1，2，3，4 時間溶体化処理を行な いただちに水冷した。この段階で各々の試料の結晶粒径 は $0.1 \mathrm{~mm}$ でほぼ一定となつた。またX線ディフラクト メータにより格子定数を測定した結果，ほとんどのマグ ネシウムが固溶していることが確認された。また予備圧 延や熱処理により，試料に優先方位が生じているかを調 べるためこの時点で集合組織を測定したが，試料の方位 はほとんど無秩序であることが確認された。

圧延は常温と低温において往復王延を行なつた。各試 料とも，50，65，85，95\%圧延したものを極点図用の試 料とした。ただし，ここでの低温压延とは試料を液体窒 素中に十分漫漬した後ただちに圧延したものであり正確 な压延温度は明らかではない。各圧延率圧延された試料 を約 $0.15 \mathrm{~mm}$ まで電解研摩し， $\mathrm{X}$ 線ディフラクトメー タにより (111) 極点図を作成した。

* 東京工業大学 (東京都) Department of Metallurgical Engineering, Tokyo Institute of Technology (Tokyo)

** 東京工業大学，現在，トヨ夕自動車工業株式会社（豊田市）Presently, at Toyota Motors Co., Ltd. (Toyota) 


\section{3. 実験 結果}

\section{1 マグネシウム添加の影響}

Fig. 1 は各試料の95\%常温圧延後の（111）極点図で， マグネシウム添加の影響を示したものである。まず，純 アルミニウム $95 \%$ 圧延のものは（Fig. 1(a)）典型的な純 金属型の圧延集合組織を示している。すなわち（146） [211]で示される方位から (112)[111]方位に分散したか たちになつている。また極点図の中心に近い集積点の強 度が非常に強く，(112)[111]方位の集積もかなり存在す ることを示している。これに対して，マグネシウム添加 量が増加すると (Fig. 1 (b)〜 (d)), 中央部の集積が横に
方位分散したかたちとなり，T.D. (圧延横方向) 付近に ある集積は, 極点図円周に近づいていく。すなわち (146)

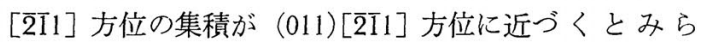
れ，合金型の成分が強くなつた結果であると考えられ る。

\section{2 圧延温度の影響}

一般に面心立方金属の場合，圧延温度を低くすればす るほど，その圧延集合組織は合金型に近いものになるこ とが多くの研究者によつて報告されている ${ }^{8), 9) 。 ~ F i g . ~} 2$ は純アルミニウムおよび $\mathrm{Al}-3 \% \mathrm{Mg}$ 合金を低温で $95 \%$ 圧延したときの (111) 極点図である。純アルミニウムに マグネシウムを添加していつた場合と同様に，圧延温度

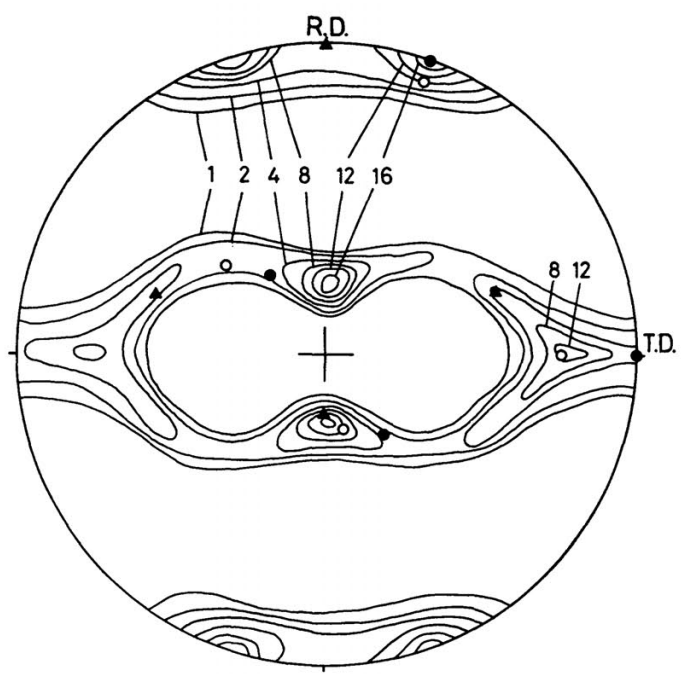

(a) Pure aluminum.

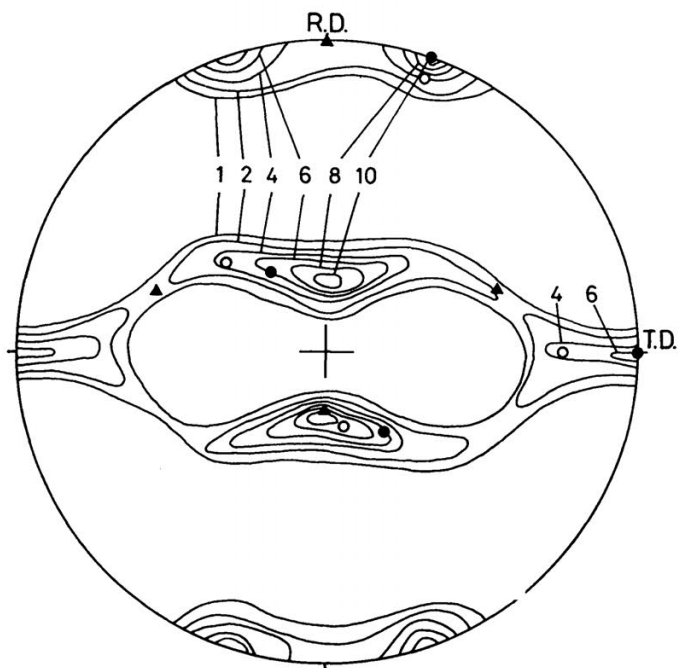

(c) $\mathrm{Al}-1.5 \% \mathrm{Mg}$.

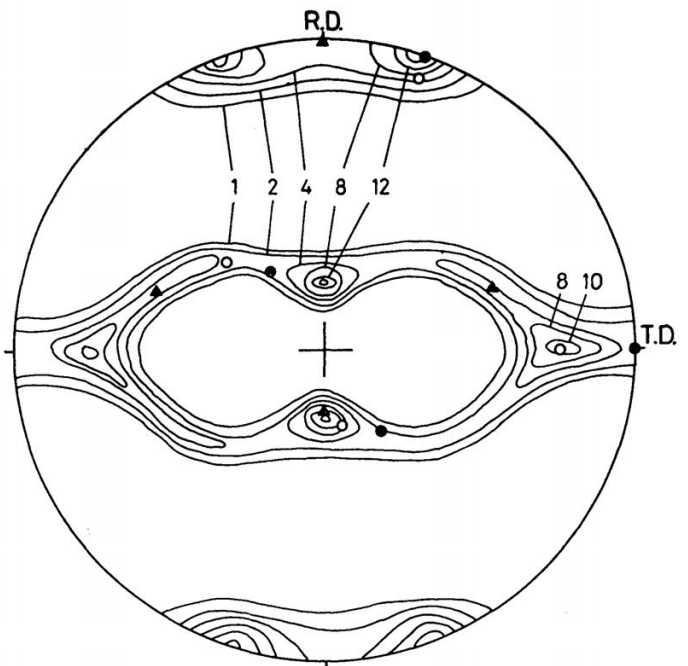

(b) $\mathrm{Al}-0.7 \% \mathrm{Mg}$.

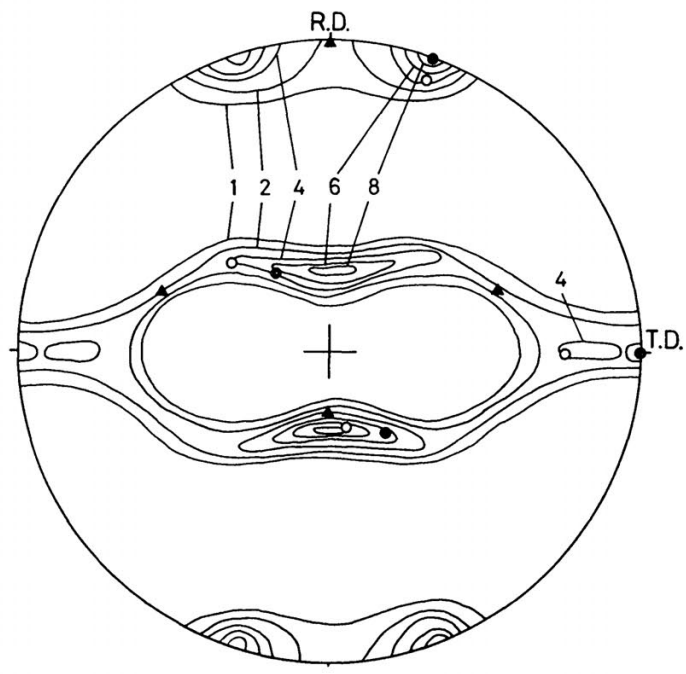

(d) $\mathrm{Al}-3 \% \mathrm{Mg}$.

Fig. 1 (111) pole figures of pure aluminum and the $\mathrm{Al}-\mathrm{Mg}$ alloy rolled to $95 \%$ reduction at room temperature.

$(011)[\overline{2} 11], \bigcirc(146)[\overline{2} 11]$

$\Delta(112)[111])$ 
を下げることによつても合金型の成分が強くなる傾向が 認められる。

以上述べた圧延集合組織の変化を，Smallman ${ }^{6)}$ が用 いた強度比 $I_{0} / I_{0}+I_{30}$ による表示法で示すと Fig. 3 のよ うになる。ここで $I_{0}, I_{30}$ は Fig. 3(a) に示したステレオ 投影図上の各点で測定した 111 回折強度である。すなわ ち， $I_{0}$ は R.P.N. (圧延面法線方向) とR.D. (圧延方 向）を結ぶ大円上での最高強度，また $I_{30}$ は大円R.P.N.R.D.を R.P.N. のまわりに $30^{\circ}$ 回転した大円上での最 高強度である。 $I_{0}, I_{30}$ はそれぞれ純金属型および合金型 の場合最高強度を示し，合金型に移行するにつれて $I_{0} /$ $I_{0}+I_{30}$ は減少する。常温, 低温圧延ともマグネシウム 添加量が增加するにつれ $I_{0} / I_{0}+I_{30}$ の值は低下してい る。また常温圧延に比べ低温圧延ではその值が低い。こ れらのことより，マグネシウム量が増加するか，圧延温 度が低くなると純金属型の成分に加えて, 合金型の成分 が強くなることがわかる。

\section{3 圧延率の影響}

Fig. 4 亿純ルミニウムの常温圧延50および65\%での （111）極点図を示す。50\%圧延では，R.P.N. と R.D. を結ぶ線上に強い集積があらわれ，T.D. 方向の集積は 弱い。すなわち，(112)[1̄11]あるいは(113)[3̄32]に近い 方位の集積があり R.P.N.のまわりの方位分散をともな つている。また $65 \%$ 圧延に㧈いても，50\%圧延と同樣の 傾向を示している。この後さらに圧延率が増加する之， R.D. 方向の（111）極は 2 つ分れ，95\%圧延になると Fig. 1(a)に示したように典型的な純金属型の圧延集合組 織となる。

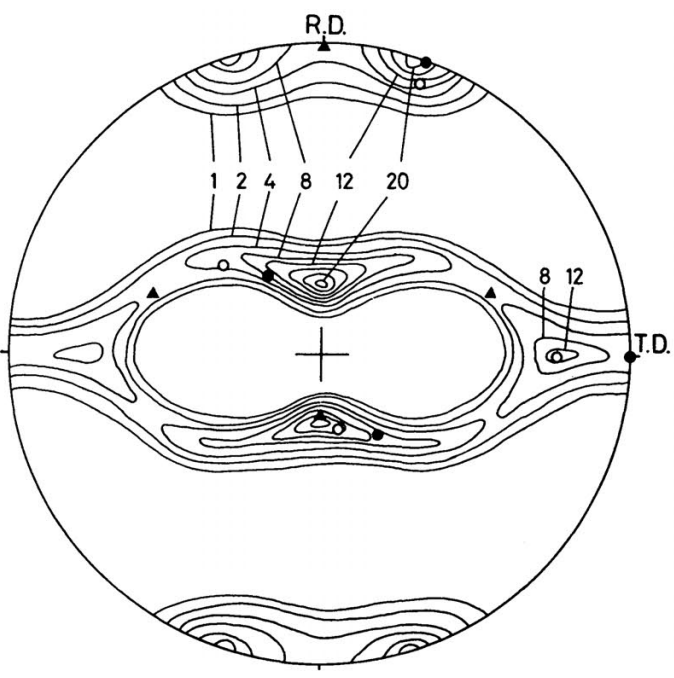

(a) Pure aluminum.
Fig. 5 に示した Al-3\% Mg 合金の場合では，50\%圧延 でやはり(112)[111]近くの集積がみられるが，65\%圧延 ではかなり純金属型に近い集積を示しており，Al-3\%

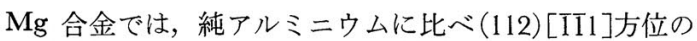
安定度は低いと考えられる。またさらに圧延率が増すと Fig. 1(d) に示したように，合金型成分の強い圧延集合 組織となる。

\section{4. 考 察}

以上述べたマグネシウム添加量や圧延率による圧延集 合組織の変化については，次のように考えられる。

50\%圧延に拈いては，純アルミニウムおよび Al-3\%

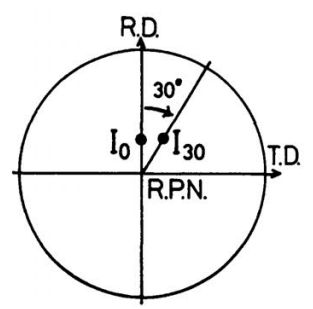

(a)

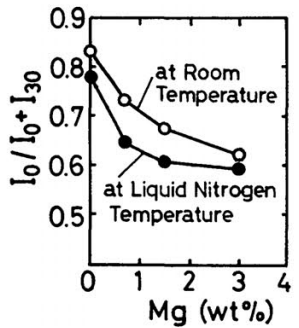

(b)
Fig. 3 Texture transition in pure aluminum and the $\mathrm{Al}-\mathrm{Mg}$ alloy.

(a) Stereograph showing the position at which $I_{0}$ and $I_{20}$ were measured.

(b) Correlation between the content of magnesium and observed intensity ratio, $I_{0} / I_{0}+$ $I_{\mathrm{s} 0}$.

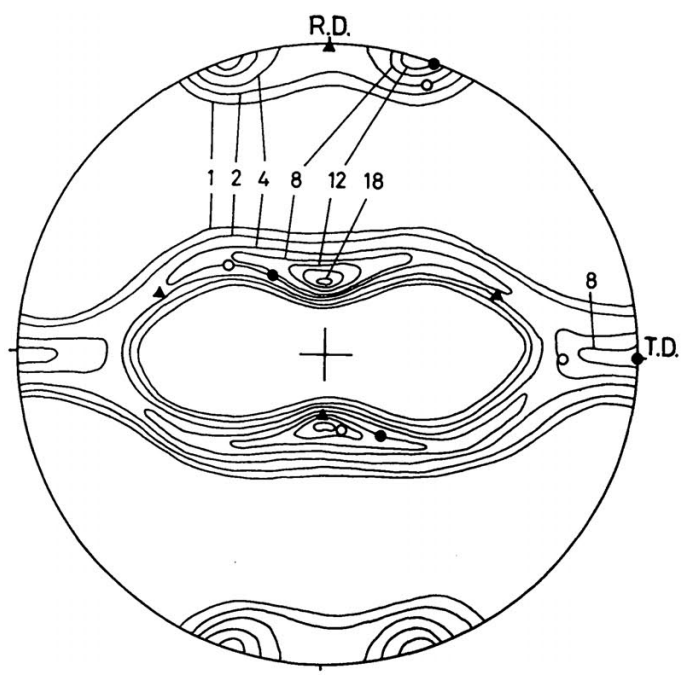

(b) $\mathrm{Al}-3 \% \mathrm{Mg}$ alloy.

Fig. 2 (111) pole figures of pure aluminum and the $\mathrm{Al}-\mathrm{Mg}$ alloy rolled to $95 \%$ reduction at liquid nitrogen temperature.

$(011)[\overline{2} 11], \quad \bigcirc(146)[\overline{2} 11], \quad \boldsymbol{\Delta}(112)[\overline{1} 11])$ 
$\mathrm{Mg}$ 合金とも(112)[111]あるいは(113)[3̄32]付近に集積 をもつ。しかし，50\%圧延の極点図に抢いては（111）極 の方位分散は P.P.N.を中心に回転したかたちをしてい ることから，圧延方向は [111］功割合に広、範囲に分 散していると考えられる。

65\%になると，純アルミニウムでは依然として(112) [111] に近い方位に集積しているのに対し，Al-3\% $\mathrm{Mg}$ 合金では (146)[211]に向から回転を起している。このこ とは，(112)[111]方位は，Al-3\% Mg 合金におけるより も純アルミニウムに㧤いてより安定であることを示する
のと思われる。

さらに圧延率が増加した場合, 純アルミニウムでは (146) [211]方位に向かつて回転するが，95\%圧延になつ

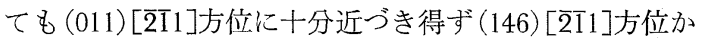
ら (112)[111]方位に分散した集積となる。これに対して $\mathrm{Al}-3 \% \mathrm{Mg}$ 合金の場合は，純アルミニウムに抒けるより も (011) [211]成分の強い圧延集合組織が発達する。

交差すべりを考虑した Dillamore ら ${ }^{3)}$ の圧延集合組織 の理諭によれば，まず一次すべりおよび共やくすべりに よつて (011)[2ㅍ1]が形成されたのち，交差すべりの活動

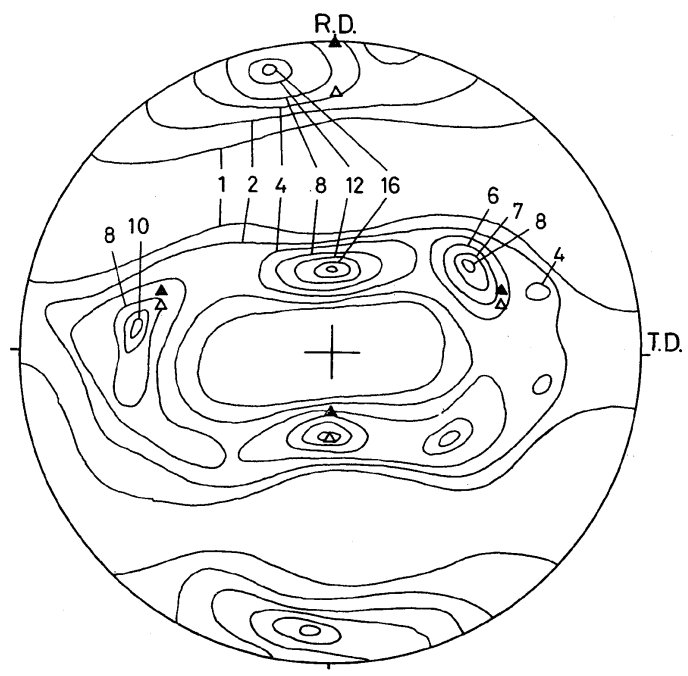

(a) Rolled to $50 \%$.

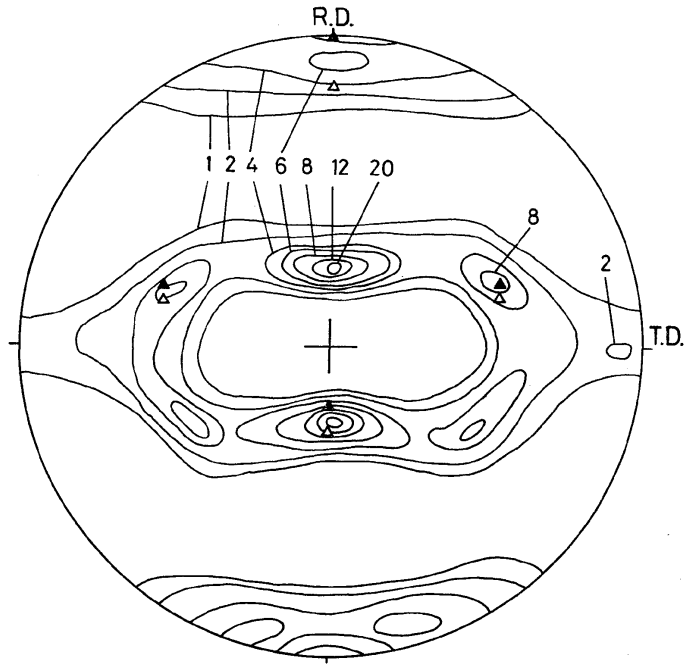

(b) Rolled to $65 \%$.

Fig. 4 (111) pole figures of pure aluminum rolled at room temperature.

$(\boldsymbol{\Delta}(112)[\overline{1} 11], \quad \triangle(113)[\overline{3} 32])$

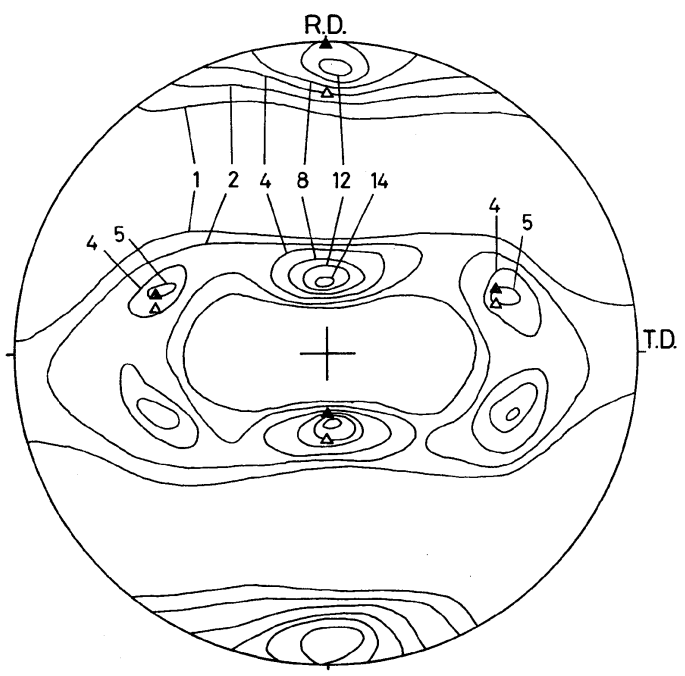

(a) Rolled to $50 \%$

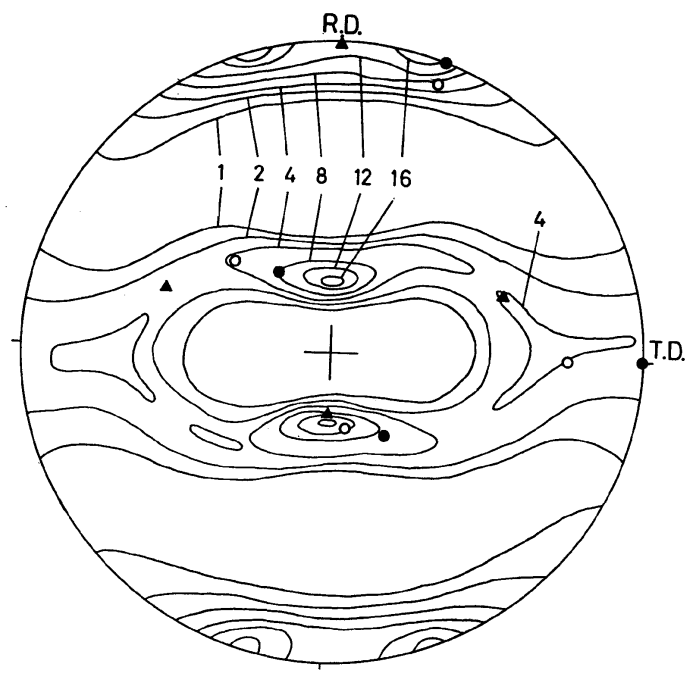

(b) Rolled to $65 \%$.

Fig. 5 (111) pole figures of the $\mathrm{Al}-3 \% \mathrm{Mg}$ alloy rolled at room temperature.

$(\mathbf{\Delta}(112)[111], \triangle(113)[\overline{3} \overline{3} 2])$ 
によつて $(146)[\overline{2} \overline{1} 1]$ ○回転を起し，純金属型の圧延集 合組織が発達すると説明される。一方 Mitra らは ${ }^{10)}$ ，ア ルミニウムに少量のマグネシウムを添加した場合，その 積層欠陥エネルギーが減少することを推測しているが， 実際にそうであるとすれば，Al-3\% Mg 合金に抢いては 積層欠陥エネルギーが減少し交差すべりを起こしにくく していると考えられる。その結果，交差すべりの活動に よる (146) $[\overline{2} \mathrm{~T} 1]$ ○回転が阻止され， $\mathrm{Al}-3 \% \mathrm{Mg}$ 合金に 抒いては (011)[211]成分が強くなつたと推察できる。し かし本実験においては， Dillamore らの報告しているよ うな $60 \%$ 程度の圧延率での (011) [211]方位の形成は認め られなかつたので，彼らの理論は完全には岕てはまらな w。

\section{5. 結言}

純アルミニウムにマグネシウムを添加した場合の圧延 集合組織を調べた結果を要約すると以下のとおりにな る。

1）純アルミニウムにマグネシウムを添加していつた 場合，圧延集合組織は純金属型から徐々に合金型に近べ き，その傾向はマグネシウム添加量とともに増大する。

2）圧延温度を低くした場合, 純アルミニウム， $\mathrm{Al}-$ $3 \% \mathrm{Mg}$ 合金とも，その圧延集合組織は純金属型から合 金型に近べく。
3）圧延率を変化させた場合, 純アルミニウム， $\mathrm{Al}-$ $3 \% \mathrm{Mg}$ 合金とも，50\%圧延では $\{112\}<111>$ 付近に集 積するが，さらに圧延率を増加させた場合，純アルミニ ウムでは $\{112\}<111>$ 成分が強く残つているのに対し， $\mathrm{Al}-3 \% \mathrm{Mg}$ 合金では，\{011\}<211>方位により近づく結 晶回転を起こす。

\section{参 考 文 献}

1) E. A. Calnan: Acta Met., 2 (1954), 865.

2) 上城：日本金属学会誌，32 (1968), 17.

3) I. L. Dillamore and W. T. Roberts: Acta Met., 12 (1964), 281.

4) G. Wassermann: Z. Metallkde., 54 (1963), 61.

5) W. Bunk: Z. Metallkde., 56 (1965), 645.

6) R. E. Smallman: J. Inst. Metals, 84 (1955/56), 10.

7) G. Wasserman: 軽金属, 17 (1967), 5.

8) H. Hu and S. R. Goodman: Trans. AIME, 227 (1963), 627.

9) R. E. Smallman and D. Green: Acta Met., 12 (1964), 145.

10) S. K. Mitra and J. E. Dorn: Trans. AIME, 227 (1963), 1015. 